\title{
Psychopathy facilitates workplace success
}

\author{
Igor Pavlić ${ }^{1}$ \\ Faculty of Media and Communications, Belgrade
}

Janko Međedović

Institute of Criminological and Sociological Research, Belgrade

\begin{abstract}
Psychopathy may be related to some adaptive outcomes in the workplace environment. This phenomenon is called corporate psychopathy and it is based on the assumption that the corporate environment positively selects for psychopathic features, especially in top management. We tested the hypothesis of positive relations between psychopathy traits and workplace success indicators in the sample of 212 working adults (69\% females; $M_{\text {age }}=33.55[S D=7.38]$ ). We measured psychopathy using the Psychopathy Personality Traits Scale (analyses were performed on two empirically extracted factors from the items of this scale, labelled as Ruthless manipulation and Lack of empathy). We explored workplace success using four variables: 1) managerial vs. operational position in the company, 2) variation in monthly salary, 3) variation in the received bonus for the previous year's performance, and 4) self-reported success in performing job tasks. Correlation and regression analyses provided very similar results: Ruthless manipulation was more pronounced in individuals who were in managerial positions, and those who received a bonus for their performance; Lack of empathy was positively associated with the bonus and self-reported performance success. Ruthless manipulation had a positive zero-order correlation with monthly salary as well, but it did not have an independent contribution to the prediction of this criterion measure. The study results are congruent with the hypothesis that psychopathy is positively associated with various indicators of success in the workplace context. The findings can be interpreted using the concepts of corporate psychopathy and successful psychopathy in general.
\end{abstract}

Keywords: success; performance; workplace; psychopathy

\section{Introduction}

Psychopathy

There are few psychological concepts that provoke such strong interest and misunderstanding at the same time as is the case with psychopathy. The

1 Igor Pavlić: igorpavlic@rocketmail.com 
mainstream view on psychopathic individuals is that they are violent and unscrupulous offenders who disregard others and unceasingly pursue their way to the highest social positions (Skeem, Polaschek, Patrick, \& Lilienfeld, 2011). Psychopathy is a term that has been subject to lengthy discussions over the years. Nowadays, the construct generally examines and includes long-lasting deviant behaviour, followed by emotional and interpersonal superficiality. The origin of the term 'psychopathy' is related to the French physician, Philippe Pinel, who applied the term insanity without delirium ('manie sans delire') to the individuals who displayed impulsive, aggressive behaviour, although they acted consciously and rationally at the same time (Patrick, Fowles, \& Krueger, 2009).

Hervey Cleckley was a pioneer in the field of psychopathy, who tried to narrow down and clarify the construct related to the existing variety of diagnoses and assuming deep emotional pathology masked as self-confident and robust appearance of these persons (Cleckley, 1941). It is interesting that Cleckley did not characterize the patients with psychopathic traits as aggressive predators who were intentionally cruel. On the contrary, he attributed the hurt they caused others to their superficial and irresponsible personality, providing three general personality traits of a psychopath: superficial charm and intelligence, absence of delusions and other signs of irrational thinking, as well as the absence of psychoneurotic manifestations. Unlike Cleckley, other influential authors of his time who focused on psychopathy in a criminal population emphasized the lack of sensibility, malice and exploitation as a part of psychopathic personality. Furthermore, McCord and McCord (1964) identified an inability to develop lasting bonds of affection with other human beings and a lack of remorse as an essential determinant of the construct. The interpersonal traits such as superficial charm or the ability to deceive and manipulate were additionally included (Lykken, 1995). Finally, some researchers of this phenomenon included antisocial behaviour as one of the core features in their definition of psychopathy (Hare, 1996). Persons with psychopathic traits were assumed to fundamentally differ from others due to a lack of basic prosocial characteristics such as empathy, remorse and poor judgement of other people's perspective (Marcus, John, \& Edens, 2004). Moreover, besides emotional deficiency, Hare (2003) also highlighted a lack of empathy and superficial emotions. All these features lead to the view of psychopathy as a personality disorder with numerous detrimental consequences for society members, mainly via amoral and antisocial behaviour. Psychopathy is often viewed as a part of the dark side of the human personality, called the Dark Triad (Paulhus \& Williams, 2002): this set of traits consists of psychopathy, Machiavellianism, and narcissism. Psychopathy, especially its markers of callousness and manipulation, is believed to be the most malevolent of them (Jones \& Figueredo, 2013). 


\section{Successful Psychopathy}

Until the 1970s, various authors had focused the research of psychopathy almost exclusively on the individuals who belonged to the clinical, forensic or inmate populations. However, it was noticed that psychopathy exists in the general population as well - the concept often labelled as subclinical psychopathy (Paulhus \& Williams, 2002). Authors usually assert that subclinical psychopathy is qualitatively the same as the one which represents disorder, but it is expressed on quantitatively lower levels than its clinical counterpart (LeBreton, Binning, \& Adorno, 2006). Furthermore, it turned out that psychopathy does not only have negative behavioural consequences. Widom (1978) suggested the term 'successful psychopath' in order to describe the persons who admitted to violating the norms of society, but avoided detention and incarceration. Other authors additionally described successful psychopaths as the ones who were persistently inclined towards intimidation within a social context, but who avoided criminal activities (Mullins-Nelson, Salekin, \& Leistico, 2006). These persons could avoid violating the society's norms but they simultaneously showed psychopathic traits, noticed in their interactions with other human beings (Hall \& Benning, 2006). Thus, the term successful psychopathy can have two meanings in the existing literature (Lilienfeld, 1998): in a narrower sense, it simply refers to the fact that some persons with psychopathic traits successfully avoid detention and paying fines, although they might get involved in criminal behaviour, while in a broader sense, it refers to the fact that psychopathy could generate a wide range of behaviours which help individuals to successfully adapt to the conditions of the environment (Međedović, 2015). Empirical data show that potential adaptive consequences of psychopathy are based on the neurobiological and physiological processes that may elevate executive functioning in successful psychopaths (reviewed in Sokić and Lukač, 2018). Behaviourally, this could be expressed by higher impulse control - a feature which could prevent detrimental behavioural outcomes in successful psychopaths (Mullins-Sweatt, Glover, Derefinko, Miller, \& Widiger, 2010).

In other words, successful psychopathy is a concept which is primarily defined by the consequences of psychopathic traits, i.e. scholars empirically observed that psychopathy did not have only socially detrimental consequences (criminal behaviour, imprisonment, substance abuse, violence etc.), but it could produce relatively adaptive behaviour (resilience to stress, short-term mating success, career advancement which results in achieving top positions in management or politics). It is not an easy task to determine when psychopathy would produce adaptive or maladaptive consequences. One direction in this task is to narrow down the concept of psychopathy. For example, many scholars agree that antisocial behaviour is not the central feature of psychopathy (e.g. Međedović, Petrović, Kujačić, Đorić, \& Savić, 
2015). Others believe that even impulsive and erratic behaviour is not the core feature of psychopathy (Boduszek, Debowska, Dhingra, \& Delisi, 2016). This is in line with the experts' notions that successful psychopathy is characterized by adequate behavioural control (Mullins-Sweatt et al., 2010). Hence, psychopathy in general cannot be easily distinguished from Machiavellianism (Miller, Hyatt, Maples-Keller, Carter, \& Lynam, 2017); furthermore, the measures of psychopathy usually contain the markers of narcissism as well (e.g. Boduszek et al., 2016; Hare, 2003). As a consequence, multidimensionally measured psychopathy has many overlapping features with the Dark Triad of personality (Glenn \& Sellbom, 2015). We believe that this represents an important conceptual problem in the field of human dark traits, but it is beyond the scope of the present manuscript.

\section{Corporate Psychopathy}

Does successful psychopathy, that is, the individuals with basic psychopathic personality traits who also achieve social success in more than one aspect of life, really exist? Some scientists state that the concept of successful psychopathy is an oxymoron by definition, taking into account the pathological correlates of psychopathy which cause difficulties in many aspects of life (Smith, Watts, \& Lilienfeld, 2014). However, the existing empirical data suggest that psychopathic traits may be more pronounced in individuals in executive or managerial positions in corporations (Boddy, Ladyshewsky, \& Galvin, 2010; Babiak \& Hare, 2006; Hare, 2003; Coid, Yang, Ullrich, Roberts \& Hare, 2009). Research studies of psychopathy in the corporate environment have been conducted in order to point out that the persons referred to as industrial or corporate psychopaths do not show typical progress of antisocial behaviour and deviant lifestyle (Babiak, 1995). According to these studies, many conditions in organizations and companies are assumed to actually represent a social and working niche which is very attractive to psychopaths (Babiak, 1995; Međedović, 2015).

Empirical research of psychopathy in the corporate environment is rare, mostly referring to self-descriptive reports and the measures of constructs similar to psychopathy such as Machiavellianism, narcissism or grandiosity (Gustafson, 2000, Gustafson \& Ritzer, 1995). According to the research conducted by Babiak and Hare (2006), individuals who were in managerial or executive positions had high scores on psychopathy measures. This indirectly shows that the persons with psychopathic traits succeed in positioning themselves at a very high level within a corporate hierarchy. The study also indicated that the employees with psychopathic traits were likely to be perceived as individuals with a leadership potential within certain companies. This perception existed despite the presence of negative marks 
of their work performance and leadership skills given by lower-ranking or subordinate employees and colleagues (Babiak \& Hare, 2006). Employees with psychopathic traits in executive positions can get over the potentially negative effects of representing themselves at the job interview and further on through their career using communication, persuasion and their interpersonal skills (Babiak, Neumann, \& Hare, 2010).

Thus, it seems that psychopathy is more pronounced in managerial positions in companies. However, the data on other indicators of workplace success are more incongruent. For example, certain findings showed that different psychopathy traits had both positive and negative relations with the participants' income (Lilienfeld, Latzman, Watts, Smith, \& Dutton, 2014). Furthermore, data showed that psychopathy was positively related to creativity, communicating skills and strategic thinking, but negatively to responsibility and job performance (Babiak et al., 2010). Finally, there are data showing negative associations between psychopathy and several workrelated outcomes like salary, leadership position and career satisfaction (Spurk, Keller, \& Hirschi, 2016). Hence, there is an incongruity in the field of psychopathy's relations with workplace behaviour, a fact that demands more empirical investigation.

\section{Goals of the present research}

The first goal of the present research is to examine whether psychopathy traits are more present in managers than workers. We were also interested in other indicators of success in the workplace context, such as monthly salary, the received bonus for work performance and self-reported success in performing job tasks. Since previous research showed that the lack of impulse control may depict unsuccessful psychopaths (Mullins-Sweatt et al., 2010), we administered the psychopathy measure which did not contain the indicators of impulsivity, disinhibition, or other behavioural problems - the Psychopathic Personality Traits Scale (PPTS: Boduszek et al., 2016). This model of psychopathy has rarely been empirically investigated so far, so the evaluation of its potential to predict the measures of workplace success is another goal of the present study. Since the PPTS model does not incorporate psychopathy features with the highest maladaptive potential (i.e. impulsivity), our hypothesis was that psychopathy features would have positive associations with all four indicators of workplace success. Thus, one of the main contributions of the present study to the existing knowledge is using the measure of psychopathy which is built on a detailed and comprehensive operationalization of psychopathic personality, i.e. the exact traits which can be assumed to facilitate workplace success (like manipulation and lack of empathy). 


\section{Method}

\section{Sample}

The measures were collected on 212 participants and the survey was conducted in Belgrade in December 2016. There were 143 female participants (67.5\%) and 69 males. All participants were employed in several companies stationed in Belgrade at the time. The data were obtained online and by paper and pencil interviewing (99 questionnaires were collected online). The second author of this report was present at the collection of the paper and pencil data; online questionnaires were collected by providing participants the link with the survey so they completed it in their free time. The age of participants varied from 18 to 56. Most participants had a secondary professional qualification $(49.5 \%)$, and $33.5 \%$ of them had a high professional degree. Working experience varied from several months to 35 years, with an average value of 7.7 years of pensionable service. There was no particular motivation for the participants in the present study: they were simply kindly asked to participate in the researched aimed to understand the relations between certain personality traits and workplace-related outcomes. Participation in the research was voluntary for all participants. All participants were employed in the companies which belong to the private sector.

\section{Measures}

We used the Psychopathic Personality Traits Scale (PPTS: Boduszek et al., 2016) to explore psychopathy. The scale is intended to measure the core aspects of psychopathic personality such as Affective responsiveness (lack of empathy, emotional callousness; item example: "I don't care if I upset someone to get what I want."), Cognitive responsiveness (inability to understand the emotional states of others; item example: "Before criticizing somebody, I try to imagine and understand how it would make them feel." [reversely coded]), Interpersonal manipulation (conning and deception; item example: "I know how to make another person feel guilty.") and Egocentricity (self-interest, disregard for others; item example: "I tend to focus on my own thoughts and ideas rather than on what others might be thinking."). It is a self-report inventory which consists of 20 items. Since previous research with the PPTS scale in Serbia did not confirm the proposed four-factor structure (Međedović, Bulut, Savić, \& Đuričić, 2018), we first performed the Principal Component Analysis on the PPTS items. Similarly to previous research, the analysis showed that two components optimally explained the variance of the observed indicators (the decision on the number of components which should be retained was made by using Parallel Analysis: Timmerman \& Lorenzo-Seva, 2011). The first extracted component (Eigenvalue $=3.62 ; 19.04 \%$ of original indicators variance explained) was loaded with the indicators of manipulation, tendency to deceive 
or insincerity, grandiose evaluation of oneself, and orientation towards one's own goals and needs; we labelled this component as Ruthless manipulation. The second component (Eigenvalue $=2.61 ; 13.75 \%$ of original indicators variance explained) was loaded with the markers of low cognitive and affective empathy and we named it Lack of empathy (the details of the Principal Components Analysis on the PPTS items can be seen in Pavlić, 2018). It can be argued that despite the results of factor analysis we could calculate the scores on four subscales as recommended by the scale authors. In fact, we performed this as well, but these scales had low reliabilities, and they could not be used in further analyses as such. That is why we decided to continue the analyses with the factor scores as the measures of psychopathy characteristics.

In order to measure workplace success, we asked the participants how high their monthly salary was and whether they received a bonus for their work performance during the previous year $(28.7 \%$ of participants declared that they had received a bonus; they were coded by 1 while the participants who did not receive bonus were coded by 0 ), and we collected information regarding whether the participant was in a managerial position within a company or not $(47.7 \%$ of participants were in a managerial position; they were coded by 1 while the participants who were at the position of worker/ operator were coded by $0^{2}$ ). Finally, we measured workplace performance $(\alpha=.84)$ via a self-report scale consisting of 7 items (this scale was constructed for the purposes of the present research). Participants evaluated the extent to which they had various abilities related to job performance (e.g. professional knowledge, competence to successfully communicate with the team, organizational abilities etc.). The response scale ranged from 1 ("I do not have this competence.") to 5 ("I have this competence to a high extent."). We provided the items of this scale in the Appendix.

\section{Results}

\section{Relations between the examined variables}

First we calculated the bivariate correlation coefficients between the explored measures. Pearson's coefficient of correlation was used as a measure of association between continuous variables. Point-biserial correlation coefficients were calculated as a measure of correlation between

2 We had two categories for this variable: workers/operators or managers; we did not distinguish individuals from low, middle and top management. Since this was one of the central variables in our research, we oversampled the managers in the present study. Having in mind the expected effect sizes, we planned to collect about 200 responses in the present survey, with roughly half of participants in the managerial positions. So, the frequency of individuals in managerial positions does not reflect actual frequency of managers in their respective companies; we simply sampled relatively same number of managers and workers in order to provide enough statistical power to conduct our analyses. 
continuous and binary variables. Due to the significant deviation from normal distribution, the measures of monthly Salary $(\mathrm{Z}=3.85 ; \mathrm{p}<.001)$ and Workplace performance $(\mathrm{Z}=2.10 ; \mathrm{p}<.001)$ were normalized first. We used the Blom's algorithm (Blom, 1958) as the most common one to normalize these two measures. The results of correlation analysis are shown in Table 1.

Table 1

Correlations between the analysed measures

\begin{tabular}{|c|c|c|c|c|c|c|c|c|c|c|}
\hline & 1. & 2. & 3. & 4. & 5. & 6. & 7. & 8. & 9. & 10. \\
\hline 1. Sex & & & & & & & & & & \\
\hline 2. Age & $-.18^{\star \star}$ & & & & & & & & & \\
\hline 3. Education & $-.15^{*}$ & $.32^{* *}$ & & & & & & & & \\
\hline 4. Work experience & -.07 & $.76^{\star *}$ & $.43^{\star *}$ & & & & & & & \\
\hline $\begin{array}{l}\text { 5. Ruthless } \\
\text { manipulation }\end{array}$ & $-.17^{\star}$ & .12 & $.24^{\star *}$ & $.17^{\star}$ & & & & & & \\
\hline 6. Lack of empathy & -.10 & .11 & .07 & .04 & .02 & & & & & \\
\hline $\begin{array}{l}\text { 7. Managerial } \\
\text { position }\end{array}$ & $-.17^{\star}$ & $.38^{* *}$ & $.70^{\star \star}$ & $.57^{\star \star}$ & $.35^{\star *}$ & .11 & & & & \\
\hline 8. Received bonus & -.10 & $.20^{* *}$ & $.37^{\star *}$ & $.36^{* *}$ & $.31^{* *}$ & $.15^{*}$ & $.67^{\star *}$ & & & \\
\hline $\begin{array}{l}\text { 9. Workplace } \\
\text { performance }\end{array}$ & -.07 & $.15^{\star}$ & .03 & $.21^{\star *}$ & -.04 & $.26^{\star *}$ & .12 & $.15^{*}$ & & \\
\hline 10. Salary & $-.16^{*}$ & $.31^{\star *}$ & $.50^{\star *}$ & $.34^{* *}$ & $.23^{\star *}$ & .08 & $.63^{* *}$ & $.46^{\star *}$ & -.04 & \\
\hline M & 1 & 33.5 & 2.99 & 7.70 & 1 & 1 & 1 & 1 & 4.46 & 118708.65 \\
\hline SD & 1 & 7.38 & 1.07 & 6.55 & 1 & 1 & 1 & 1 & 0.46 & 73319.25 \\
\hline
\end{tabular}

As expected, all workplace success measures correlated positively among themselves. Only the relation between Workplace performance and salary was non-significant. Ruthless manipulation correlated positively with Managerial position, Received bonus and monthly Salary; Lack of empathy was positively associated with Received bonus and Workplace performance. It is interesting to mention that Ruthless manipulation was positively correlated with Education and Work experience as well. The range of detected effect sizes was high - it ranged from low to high effect sizes; however, the effect sizes of the associations between psychopathy traits and indicators of workplace success were low to moderate.

\section{Psychopathy traits as the predictors of workplace success}

In order to examine whether psychopathy traits can predict the measures of workplace success, we set four regression models. Psychopathy traits were set as predictor measures, together with participants' sex, age, education and 
work experience; workplace success measures were set as criteria variables. All of the obtained regression functions were statistically significant. We reported Cox and Snell's pseudo- $\mathrm{R}^{2}$ in the binary logistic regression models since it is based on more conservative estimations. The results of the regression analysis are shown in Table 2.

Table 2

Psychopathy traits as the predictors of workplace success measures

\begin{tabular}{|c|c|c|c|c|c|c|c|c|}
\hline & \multicolumn{2}{|c|}{$\begin{array}{l}\text { Workplace } \\
\text { performance }\end{array}$} & \multicolumn{2}{|c|}{ Salary } & \multicolumn{2}{|c|}{$\begin{array}{l}\text { Managerial } \\
\text { position }\end{array}$} & \multicolumn{2}{|c|}{ Received bonus } \\
\hline & $\beta$ & S.E. & $\beta$ & S.E. & $\exp (\beta)$ & S.E. & $\exp (\beta)$ & S.E. \\
\hline 1. Sex & -.08 & .07 & -.07 & .04 & 2.59 & .53 & 1.34 & .40 \\
\hline 2. Age & -.11 & .01 & .07 & .00 & 0.88 & .08 & $0.88^{*}$ & .06 \\
\hline 3. Education & -.07 & .03 & $.39^{* *}$ & .02 & $5.71^{\star *}$ & .28 & $1.73^{* *}$ & .19 \\
\hline 4. Work experience & $.34^{\star *}$ & .01 & .09 & .00 & $1.37^{\star *}$ & .08 & $1.23^{\star *}$ & .06 \\
\hline $\begin{array}{l}\text { 5. Ruthless } \\
\text { manipulation }\end{array}$ & -.08 & .03 & .10 & .02 & $2.10^{* *}$ & .25 & $1.87^{\star *}$ & .19 \\
\hline 6. Lack of empathy & $.26^{\star *}$ & .03 & .03 & .02 & 1.54 & .28 & $1.68^{*}$ & .21 \\
\hline $\mathrm{F} / \chi^{2}$ & \multicolumn{2}{|c|}{$4.775^{\star \star}$} & \multicolumn{2}{|c|}{$12.589^{\star *}$} & \multicolumn{2}{|c|}{$161.479^{* *}$} & \multicolumn{2}{|c|}{$59.101^{\star *}$} \\
\hline $\mathrm{R}^{2}$ & \multicolumn{2}{|c|}{.13} & \multicolumn{2}{|c|}{.28} & \multicolumn{2}{|c|}{.55} & \multicolumn{2}{|c|}{.26} \\
\hline
\end{tabular}

Notes: ${ }^{\star}-\mathrm{p}<.05 ;{ }^{*}-\mathrm{p}<.01$.

The regression analysis mostly confirmed bivariate associations between the examined variables. Ruthless manipulation positively predicted whether the participants were in a Managerial position and if they had received a bonus for the previous year performance. Lack of empathy had an independent positive contribution to the prediction of Workplace performance and the Received bonus. The only zero-order association which was not confirmed in the regression analysis was the one between Ruthless manipulation and Salary - participants' education was the only significant predictor of this workplace success measure. The percentages of criteria's explained variance ranged from small to moderate.

\section{Discussion}

The research on the role of psychopathy in the workplace context is relevant on various grounds. It is scientifically important since it can show whether a behavioural disposition with mostly detrimental and maladaptive outcomes can show some adaptive features as well. On the other hand, it is also relevant in a practical context: even if corporate psychopathy may be adaptive for psychopathic individuals themselves, it still has negative impacts both on companies where these individuals work (O'Boyle, Forsyth, Banks, \& McDaniel, 2012) and other employees (Tokarev, Phillips, Hughes, \& Irwing, 2017; Volmer, Koch, \& Göritz, 2016). In the present research, we tested the 
hypothesis that psychopathy was positively associated with several indicators of workplace success. This hypothesis was confirmed, and, hence, the present study showed that psychopathic traits could have some adaptive features which can be expressed in the workplace environment.

\section{Psychopathy and the indicators of workplace success}

Psychopathic traits, or, more precisely, Ruthless manipulation and Lack of empathy, turned out to be positively associated with several indicators of workplace success. Low levels of empathy were positively associated with the self-reported job performance and more pronounced in the individuals who received a bonus. Manipulative traits were shown to be especially useful in a working niche: they were more pronounced in managers and individuals who had obtained a bonus for their previous year performance, and they were positively related to the amount of participants' salary. This said, it should be mentioned that the last connection was not confirmed in the regression analysis - only education was an independent predictor of salary. Having in mind that correlation analysis showed a positive relation between education and Ruthless manipulation, we can explain the lack of association between psychopathy and salary in the regression model by proposing a mediation hypothesis: the association between psychopathy and salary is mediated by the education level. More precisely, individuals who are prone to manipulation achieve higher education, and via the elevated educational level they can earn more money. This explanation can be corroborated by recent findings that individuals with low scores on the Honesty-Humility personality trait (i.e. more insincere, unfair and narcissistic - personality characteristics similar to psychopathy) may achieve higher academic achievement (Janošević \& Petrović, 2019). This hypothesis should be empirically tested in future research.

These results are congruent with previous findings of psychopathy's higher frequency in managers (Babiak \& Hare; Babiak et al., 2010; Board \& Fritzon, 2005) and the positive associations between psychopathy and leadership (Lilienfeld et al., 2014). How do psychopathic individuals achieve high positions in companies? Babiak's model (Babiak, 1995) explains that in the context of corporate dynamics and frequent fluctuation of employees, the persons with psychopathic traits adapt easily using the coalitions they create with the like-minded individuals and antagonizing opponents. Moreover, the persons with psychopathic traits manipulate their co-workers, charm their superiors and represent themselves as ideal leaders (Furnham, 2007), while at the same time intimidating the ones in lower-ranking positions in order to create a toxic work environment. Thus, the main pathway of psychopaths towards workplace success is manipulation. Psychopathic traits help the individuals to present themselves in a way which is suitable for managerial 
positions. These characteristics can be easily associated with leadership skills, that is, a person is attributed self-confidence and a charismatic leadership style instead of, for example, grandiosity. Moreover, emotional superficiality, a lack of insight, empathy and remorse are easily perceived as toughness and strength to stay calm in a stressful and dynamic work environment within the corporate setting (Babiak et al., 2010).

\section{Corporate psychopathy: overcoming the incongruent findings}

Although congruent with the data of elevated psychopathy in managers, the present results are not in line with some findings regarding psychopathy and a wider range of workplace success outcomes. For example, previous findings have shown negative correlations between work performance (O'Boyle et al., 2012; Smith, Craig Wallace, \& Jordan, 2016), the amount of personal income (Lilienfeld, et al., 2014) and psychopathy. How can this discrepancy in findings be explained? When we observe the operationalizations of psychopathy in the above-mentioned studies compared to the present research, it is quite clear that the source of heterogeneity in the results is the use of various inventories for measuring psychopathy. In previous studies, unidimensional measures of psychopathy were used, the ones in which psychopathy was operationalized via a single score. These measures generally have a narrow range of indicators and are often biased towards certain markers of psychopathy. For example, the measure of psychopathy from the Short Dark Triad inventory (SD3: Jones \& Paulhus, 2014) is fairly saturated with impulsivity markers, and psychopathy from the Dirty Dozen questionnaire (Jonason \& Webster, 2010) dominantly assesses the lack of empathy. It is clear that these measures must yield different results compared to those where psychopathy is operationalized in a comprehensive and multidimensional manner (this is particularly relevant to the SD3 measure of psychopathy, which is often used in research and which, in fact, examines maladaptive or unsuccessful psychopathy in the light of accentuated impulsivity and vindictiveness). On the other hand, previous research has shown that the trait of Machiavellianism (which depicts manipulative and deceitful behaviour and is therefore similar to the factor of Ruthless Manipulation isolated in this study) is positively related to the amount of personal income (Lindley, 2018; Spurk et al., 2016). In sum, researchers should be very careful regarding the specific measure of psychopathy they use in their research, and interpret their findings in the light of the administered scale's content. Furthermore, there is obviously a conceptual overlap between the Dark Triad concept and multidimensional measures of psychopathy. Machiavellianism, narcissism and psychopathy are considered as separate traits in the Dark Triad (Paulhus \& Williams, 2002), while the multidimensional models of psychopathy frequently see all of them as a part of the psychopathy concept (Boduszek et al., 2016; Hare, 2003). 
Implications for the successful psychopathy concept

Psychopathy measured by the PPTS scale positively predicted all analysed indicators of workplace success. This result is certainly dependent on the fact that the PPTS consists of psychopathic personality markers (manipulation, egocentricity, lack of empathy), but it does not measure disinhibition, impulsiveness and antisocial behaviour (Boduszek et al., 2016). Hence, it could be said that the inventory captures the psychopathy characteristics which have the highest adaptive potential, since previous findings showed that successful psychopaths may have adequate impulse control (Mullins-Sweatt et al., 2010). Other findings are in line with this hypothesis: for example, previous research showed that manipulative and callous psychopathic traits were positively related to income, while the relation between impulsive and antisocial traits with income was negative (Lilienfeld et al., 2014). Furthermore, the data showed that managers have more pronounced manipulative and egocentric characteristics, but low expressions of disinhibition and antisocial behaviour (Board \& Fritzon, 2005). The results of present and previous studies suggest that psychopathic personality traits (emotional coldness, egocentricity and manipulation) may have an adaptive consequence if the trait impulsiveness is lacking. This assumption would be in accordance with the dual-process model of successful psychopathy (Hall \& Benning, 2006). This model supposes that manipulative-affective psychopathy traits are etiologically different from the impulsive-antisocial psychopathy markers (Fowles, \& Dindo, 2006). Because of their different etiologies, these traits can be differentially pronounced in individuals: some individuals may have elevated manipulative-affective psychopathy characteristics, but at the same time low levels of impulsive and antisocial behaviour, and vice versa. In this context, the former phenotype would reflect successful psychopathy. Certainly, this assumption should be empirically evaluated in future research.

\section{Limitations and future directions}

The present study has some apparent limitations. The sample size was relatively low. This obviously did not prevent us from detecting statistically significant effects, but it did buffer some additional analyses which could be conceptually important (e.g. examining the role of sex as a potential moderator in the relations between psychopathy and workplace success). Furthermore, the present research is a mono-methodic study: all variables were collected using the same source - the participants themselves. This could especially affect the associations between psychopathy and workplace performance: they may be overestimated due to the fact that these measures were collected via the self-report Likert-type scales. Hence, it would be useful to gather the 
data regarding psychopathy using ratings or other observer methods, which could further enhance the reliability of the present findings. We emphasize that this is the second study where the expected latent structure of the PPTS was not confirmed (together with the Međedović et al., 2018) - this finding suggests that further psychometric work on the scale could be fruitful.

It is also important to mention that companies and firms in Serbia work in a relatively specific context: many working organizations still operate by leaning on formal or informal rules which were implemented in the socialistic political system. Furthermore, the labour laws in Serbia are not fully developed to protect the rights of workers, while the ones which exist are often not implemented in practice. It is possible that organizations with highly developed human resource practice may diminish the chance of psychopathic individuals to achieve work-related success in several ways: 1) by establishing the set of values which is incongruent with the dark personality traits; 2) by detecting psychopathic characteristics during professional selection; 3) by establishing the system of workplace performance which is sensitive to behavioural manifestations of manipulation and interpersonal antagonism, and 4) by compliance with the legal procedure, in particular the Law on the prohibition of mobbing, the Law on the protection of whistleblowers and the Law on the prohibition of discrimination. Hence, the specific context of Serbian working organizations certainly poses an obstacle to the generalization of the current findings. Future studies should examine if the positive link between psychopathy traits and some indicators of workplace success would hold in different working systems.

Future research could benefit from examining both the moderators and mediators of the link between psychopathy and workplace outcomes (moderators have the central role in the so-called moderated expression model of successful psychopathy: Hall \& Benning, 2006). Potential moderators include sex, family and the economic background of an individual, intelligence, education etc. The search for mediators would be based on the exploration of the exact ways, tactics, and behaviours the psychopathic individuals use to achieve their goals in companies, or fail to do so. In any case, further research of corporate and successful psychopathy is highly needed in order to understand this complex personality syndrome, especially due to the fact that, despite personal success, corporate psychopathy may have negative consequences for a large number of people who share their workplace environment with psychopathic individuals (Tokarev et al., 2017; Volmer et al., 2016). Hence, the research in corporate psychopathy should provide scientific background in establishing protective mechanisms which could shield individuals from psychopathic influence without decreasing company productivity. 


\section{Concluding remarks}

Psychopathy is certainly an intriguing topic in the field of human individual differences. One of the reasons for this is the potential of psychopathy to induce harm and cost for an individual. This damage can be increased if psychopathic individuals can place themselves in high societal positions, perhaps as political leaders or company CEOs. The present research represents a contribution to the literature of how psychopathy may enhance individual success and thus help in advancing someone's social and economic status. Studies covering these topics are necessary in order to understand potentially adaptive characteristics of psychopathy, but also to prevent harm to society which may result form the psychopaths who hold distinguished roles in a certain group.

\section{References}

Babiak, P. (1995). When psychopaths go to work: A case study of an industrial psychopath. Applied Psychology: An International Review, 44, 171-188. https:// doi.org/10.1111/j.1464-0597.1995.tb01073.x

Babiak, P., \& Hare, R. D. (2006). Snakes in suits: When psychopats go to work. New York, NY: HarperCollins.

Babiak, P., Neumann, C. S., \& Hare, R. D. (2010). Corporate psychopathy: Talking the walk. Behavior Sciences \& the Law, 28, 174-193. https://doi.org/10.1002/bsl.925

Blom, G. (1958). Statistical estimates and transformed beta-variables. New York, NY: John Wiley \& Sons.

Board, B. J., \& Fritzon, K. (2005). Disordered personalities at work. Psychology, Crime \& Law, 11, 17-32. https://doi.org/10.1080/10683160310001634304

Boddy, C. R., Ladyshewsky, R., \& Galvin, P. (2010). Leaders without ethics in global business: Corporate psychopaths. Journal of Public Affairs, 10, 121-138. https:// doi.org/10.1002/pa.352

Boduszek, D., Debowska, A., Dhingra, K., \& Delisi, M. (2016). Introduction and validation of Psychopatic Personality Traits Scale (PPTS) in a large prison sample. Journal of Criminal Justice, 46, 9-17. https://doi.org/10.1016/j.jcrimjus.2016.02.004

Cleckley, H. (1941). The mask of sanity. St. Louis, MO: Mosby.

Coid, J., Yang, M., Ullrich, S., Roberts, A., \& Hare, R. D. (2009). Prevalence and correlates of psychopathic traits in the household population of Great Britain. International Journal of Law and Psychiatry, 32, 65-73. https://doi.org/10.1016/j. ijlp.2009.01.002

Fowles, D. C., \& Dindo, L. (2006). A dual-deficit model of psychopathy. In C. J. Patrick (Ed.), Handbook of psychopathy (pp. 14-34). New York, NY: Guilford Press.

Furnham, A. (2007). Personality disorders and derailment at work: The paradoxical influence of pathology in the workplace. In J. Langan-Fox, C. L. Cooper, \& R. J. Kli- 
moki (Eds.), Research companion to the dysfunctional workplace: Management challenges and symptoms (pp. 22-39). Northampton, MA: Edward Elgar Publishing, Inc.

Glenn, A. L., \& Sellbom, M. (2015). Theoretical and empirical concerns regarding the dark triad as a construct. Journal of Personality Disorders, 29, 360-377. https:// doi.org/10.1521/pedi_2014_28_162

Gustafson, S. B. (2000). Personality and organizational destructiveness: Fact, fiction, and fable. In L. R. Bergman, R. B. Cairns, L. Nilsson, \& L. Nystedt (Eds.), Developmental science and the holistic approach (pp. 299-314). Mahwah, NJ: Erlbaum.

Gustafson, S. B., \& Ritzer, D. R. (1995). The dark side of normal: A psychopathy-linked pattern called aberrant self-promotion. European Journal of Personality, 9, 147-183. https://doi.org/10.1002/per.2410090302

Hall, J. R., \& Benning, S. D. (2006). The „successfull“ psychopath: Adaptive and subclinical manifestations of psychopathy in the general population. In C. J. Patrick's (Ed.), Handbook of psychopathy (pp. 459-478). New York, NY: Guilford Press.

Hare, R. D. (1996). Psychopathy: A clinical construct whose time has come. Criminal Justice and Behavior, 23, 25-34. https://doi.org/10.1177\%2F0093854896023001004

Hare, R. D. (2003). Manual for the Revised Psychopathy Checklist (2nd ed.). Toronto, ON, Canada: Multi-Health Systems.

Jones, D. N., \& Figueredo, A. J. (2013). The core of darkness: Uncovering the heart of the Dark Triad. European Journal of Personality, 27, 521-531. https://doi. org/10.1002/per.1893

Janošević, M., \& Petrović, B. (2019). Effects of personality traits and social status on academic achievement: Gender differences. Psychology in the Schools, 56, 497509. https://doi.org/10.1002/pits.22215

Jonason, P. K., \& Webster, G. D. (2010). The dirty dozen: A concise measure of the dark triad. Psychological Assessment, 22, 420-432. doi:10.1037/a0019265

Jones, D. N., \& Paulhus, D. L. (2014). Introducing the short dark triad (SD3) a brief measure of dark personality traits. Assessment, 21, 28-41. https://doi. org/10.1177\%2F1073191113514105

LeBreton, J. M., Binning, J. F., \& Adorno, A. J. (2006). Subclinical psychopaths. In J. C. Thomas \& D. Segal (Eds.), Comprehensive handbook of personality and psychopathology, Vol. 1 (pp. 388-411). New York, NY: Wiley.

Lilienfeld, S. O. (1998). Methodological advances and developments in the assessment of psychopathy. Behaviour Research and Therapy, 36, 99-125. https://doi. org/10.1016/S0005-7967(97)10021-3

Lilienfeld, S. O., Latzman, R. D., Watts, A. L., Smith, S. F., \& Dutton, K. (2014). Correlates of psychopathic personality traits in everyday life: Results from a large community survey. Frontiers in Psychology, 5, 740. https://doi.org/10.3389/ fpsyg.2014.00740

Lindley, J. K. (2018). Are there unexplained financial rewards for the Snakes in suits? A labour market analysis of the Dark Triad of personality. British Journal of Industrial Relations, 54, 770-797. https://doi.org/10.1111/bjir.12269

Lykken, D. T. (1957). A study of anxiety in the sociopathic personality. Journal of Abnormal and Social Psychology, 55, 6-10. 
Marcus, D. K., John, S., \& Edens, J. F. (2004). A taxometric analysis of psychopathic personality. Journal of Abnormal Psychology, 113, 626 - 635. http://psycnet.apa. org/doi/10.1037/0021-843X.113.4.626

McCord, W., \& McCord, J. (1964). The psychopath: An essay on the criminal mind. Oxford, England: D. Van Nostrand.

Međedović, J. (2015). Nomološka mreža psihopatije [Nomological network of psychopathy]. Beograd, Srbija: Institut za kriminološka i sociološka istraživanja.

Međedović, J., Bulut, T., Savić, D., \& Đuričić, N. (2018). Delineating psychopathy from cognitive empathy: the case of Psychopathic Personality Traits Scale. European Journal of Analytic Philosophy, 14, 53-62. https://doi.org/10.31820/ ejap.14.1.3.

Međedović, J., Petrović, B., Kujačić, D., Đorić, J. Ž., \& Savić, M. (2015). What is the optimal number of traits to describe psychopathy? Primenjena psihologija, 8(2), 109-130.

Miller, J. D., Hyatt, C. S., Maples-Keller, J. L., Carter, N. T., \& Lynam, D. R. (2017). Psychopathy and Machiavellianism: A distinction without a difference? Journal of Personality, 85, 439-453. https://doi.org/10.1111/jopy.12251

Mullins-Nelson, J. L., Salekin, R. T., \& Leistico, A. R. (2006). Psychopathy, empathy, and perspective-taking ability in a community sample: Implications for the successful psychopathy concept. International Journal of Forensic Mental Health, 5, 133-149. https://doi.org/10.1080/14999013.2006.10471238

Mullins-Sweatt, S. N., Glover, N. G., Derefinko, K. J., Miller, J. D., \& Widiger, T. A. (2010). The search for the successful psychopath. Journal of Research in Personality, 44, 554-558. https://doi.org/10.1016/j.jrp.2010.05.010

O’Boyle, E. H., Forsyth, D. R., Banks, G. C., \& McDaniel, M. A. (2012). A metaanalysis of the dark triad and work behavior: A social exchange perspective. Journal of Applied Psychology, 97, 557-579. doi:10.1037/a0025679

Patrick, C. J., Fowles, D. C., \& Krueger, R. F. (2009). Triarchic conceptualization of psychopathy: Developmental origins of disinhibition, boldness, and meanness. Development and Psychopathology, 21, 913-938. https://doi.org/10.1017/ S0954579409000492

Paulhus, D. L., \& Williams, K. M. (2002). The dark triad of personality: Narcissism, Machiavellianism, and psychopathy. Journal of Research in Personality, 36(6), 556-563. https://doi.org/10.1016/S0092-6566(02)00505-6

Skeem, J. L., Polaschek, D. L. L., Patrick, C. J., \& Lilienfeld, S. O. (2011). Psychopathic personality: Bridging the gap between scientific evidence and public policy. Psychological Science in the Public Interest, 12, 95-162. https://doi. org/10.1177\%2F1529100611426706

Smith, M. B., Craig Wallace, J., \& Jordan, P. (2016). When the dark ones become darker: How promotion focus moderates the effects of the dark triad on supervisor performance ratings. Journal of Organizational Behavior, 37, 236-254. https://doi.org/10.1002/job.2038

Smith, S. F., Watts, A. L., \& Lilienfeld, S. O. (2014). On the trail of the elusive successful psychopath. The Psychologist, 15, 340-350. 
Sokić, K., \& Lukač, M. (2018). Uspješna psihopatija: stvarnost ili mit. FIP-Financije i pravo, 6(1), 7-28.

Spurk, D., Keller, A. C., \& Hirschi, A. (2016). Do bad guys get ahead or fall behind? Relationships of the dark triad of personality with objective and subjective career success. Social Psychological \& Personality Science, 7, 113-121. https://doi. org/10.1177\%2F1948550615609735

Timmerman, M. E., \& Lorenzo-Seva, U. (2011). Dimensionality assessment of ordered polytomous items with parallel analysis. Psychological Methods, 16, 209220. http://psycnet.apa.org/doi/10.1037/a0023353

Tokarev, A., Phillips, A. R., Hughes, D. J., \& Irwing, P. (2017). Leader dark traits, workplace bullying, and employee depression: Exploring mediation and the role of the dark core. Journal of Abnormal Psychology, 126, 911-920. http://psycnet. apa.org/doi/10.1037/abn0000299

Volmer, J., Koch, I. K., \& Göritz, A. S. (2016). The bright and dark sides of leaders' dark triad traits: Effects on subordinates' career success and well-being. Personality and Individual Differences, 101, 413-418. https://doi.org/10.1016/j. paid.2016.06.046

Widom, C. S. (1978). A methodology for studying non-institutionalized psychopaths. In R. D. Hare \& D. Schalling (Eds.), Psychopathic behavior: Approaches to research (pp. 71-84). Toronto, Ontario, Canada: Wiley.

\section{Psihopatija potpomaže uspeh u radnom okruženju}

\section{Igor Pavlić}

Fakultet za medije i komunikacije, Beograd

\section{Janko Međedović}

Institut za kriminološka i sociološka istraživanja, Beograd

Postoje indicije da je psihopatija povezana sa nekim adaptivnim ishodima u radnom okruženju. Ovaj fenomen je nazvan korporativna psihopatija i bazira se na pretpostavci da korporativno okruženje pozitivno selektuje osobe sa psihopatskim karakterisitkama, pogotovo na menadžerskim pozicijama. U ovom istraživanju testirali smo hipotezu o pozitivnim relacijama između psihopatije i indikatora uspeha u radnom okruženju na uzorku od 212 odraslih zaposlenih lica (69\% ženskog pola; $\mathrm{AS}_{\text {uzrast }}=33.55$ godina $[\mathrm{SD}=7.38]$ ). Psihopatija je merena pomoću Skale Psihopatskih Crta Ličnosti (analize su sprovedene na dva empirijski ekstrahovana faktora iz ajtema ove skale, imenovanih Bezosećajna manipulacija i Nedostatak empatije). Uspešnost na radnom mestu je merena pomoću četiri varijable: 1) menadžerska nasuprot operatorskoj radnoj poziciji; 2) varijacije u mesečnom ličnom dohotku; 3) varijacija u primljenom bonusu za prošlogodišnji performans i 4) samoprocenjena radna uspešnost. Korelaciona i regresiona analiza rezultirale su u veoma sličnim nalazima: Bezosećajna manipulacija je bila više izražena kod osoba 
koje su na menadžerskim pozicijama i kod onih koji su dobili bonus za prošlogodišnji preformans; Nedostatak empatije je pozitivno predviđao bonus za prošlogodišnji performans i samoprocenjenu radnu sposobnost. Bezosećajna manipulacija je pokazala i pozitivnu korelaciju nultog reda sa mesečnim ličnim dohotkom ali nije imala nezavistan doprinos pri predikciji ovog kriterijuma. Dobijeni rezultati su kongruentni sa postavljenom hipotezom: psihopatija je pozitivno povezana sa indikatorima uspešnosti na random mestu. Rezultati se mogu interpretirati pomoću koncepata korporativne I uspešne psihopatije.

Ključne reči: uspeh; uspešnost na radu; radno mesto; psihopatija 


\section{Appendix \\ The workplace performance self-report scale}

We will present you several characteristics related to the workplace environment. We would like to ask you to evaluate to what extent you express each of these characteristics. Number 1 stands for "I do not possess this characteristic at all", while number 5 stands for "I possess this characteristic to a high extent".

\begin{tabular}{|l|l|c|c|c|c|c|}
\hline & Professional knowledge - knowledge of the particular work I do & 1 & 2 & 3 & 4 & 5 \\
\hline & Ability to communicate with the team, associates and subordinates & 1 & 2 & 3 & 4 & 5 \\
\hline & Ability to apply knowledge and solve complex situations & 1 & 2 & 3 & 4 & 5 \\
\hline $\begin{array}{l}\text { A sense of organization, rationalization, coordination and } \\
\text { cooperation }\end{array}$ & 1 & 2 & 3 & 4 & 5 \\
\hline Autonomy and responsibility in work & 1 & 2 & 3 & 4 & 5 \\
\hline Willingness to take responsibility and risk & 1 & 2 & 3 & 4 & 5 \\
\hline Ability to plan, decide and motivate associates & 1 & 2 & 3 & 4 & 5 \\
\hline
\end{tabular}

